\title{
EMPIRICAL PARKING STUDY IN UNIVERSITY OF DUHOK CAMPUS
}

\author{
NAHLA ALASWADKO ${ }^{1}$ \\ Dept. of Civil Engineering, College of Engineering, University of Duhok, Kurdistan Region-Iraq
}

(Accepted for Publication: December 8, 2020)

\begin{abstract}
University of Duhok campus in Duhok city, Kurdistan region, Iraq, suffers from a serious mobility problems and illegal on-street parked cars resulting from continuous development of campus without proper policy and program to control the problem. The aim of this paper is to present empirical parking study in University of Duhok (UoD) campus by assessing and examining the present supply of parking. Besides, it aims to find the maximum expected number of parking spaces that would be able to accommodate the current parked vehicles, and the expected number of parking spaces to accommodate the future demand of spaces. Several related parking surveys were conducted in the university campus, involved: current parking supply, computing the available off street parking capacity, license plate survey and questionnaire survey for campus parkers. The UoD main campus inventory results indicated that there are 2,027 available spaces which distribute on 27 lots. Campus parkers' behavior has been evaluated from quantitative samples (more than 600) of parkers. Data was collected laterally nine hours by observing and recording the vehicles license plate number to study vehicles parking duration. It was observed that a massive number of vehicles were parked with short parking duration and the maximum parking index was appeared from 10:30 a.m. to 11:00 a.m. With the continuous progress in campus population and land uses development for different purposes, the UoD main campus suffers from insufficient supply spaces for parkers. In addition to that, it is estimated that the parking spaces demand will remain to growth in the forthcoming years due to the campus circumstance.
\end{abstract}

KEYWORDS: Parking characteristics; Parking duration; University campuses; Parking inventories; Parking surveys; Parking index.

\section{OVERVIEW}

F ormerly and still, there are a number of challenges that facing university campuses because of continuous growing parking spaces shortage, traffic movement and congestion, and deficiency of proper public transport system (Coulson et al., 2011). In the context of university campus parking study, a number of studies have been reviewed and generally revealed that the campus parking study evaluated supply parking and future demand parking. In addition to that different recommendations and solutions were provided based on each university campus environment. An early state-of-the-art review has been conducted by Janak et al. (2020) to integrate all parking aspects and suggest that superior consideration should be specified to parkers and parking characteristics. These characteristics are ease of parking access, time spent for walking, charges of parking, provided regulations and information system, applied management system, etc. It also affords valuable information for planning, designing and evaluating general parking systems.

To reduce parking demand at the American University of Beirut, a study conducted by Aoun 
et al. (2013) indicated that increasing parking supply is not a practical resolution for the shortage of parking, but it attracts more drivers, and caused more congestion. The authors also found that parking strategies are effective in developed world contexts, but their benefits will not be recognized in cases where regulation enforcement is absent and parking requirement is prevalent. Huayan et al. (2007) examined the campus parking problem for one on china universities as a case study, the Beijing University of Aeronautics and Astronautics (BUAA). In this study, the authors were suggested to count the arriving and departing vehicles at university campus gates to compute the parking duration of each parked vehicle. The campus parking characteristics and problems had been presented and concluded that same characteristics and problems that were found on the BUAA campus frequently available in further Chinese universities and similar approach can be utilized to study other campus parking systems. In Al- Mustansiriya university campus in Iraq, a parking study carried out to assess and examine the available parking supply and the expected parking demand for a target year. The study revealed that additional parking spaces are required for the selected target year to provide somewhere to stay the anticipated future demand. These results were based on three expected factors, which are: more campus population development, more usage of passenger cars and further land use development (Sofia et al., 2012).

A comprehensive research related to characteristics of universities parking systems was reported by Cheu et al. (2018). Their study set out three main objectives which are: review and compare the parking demand and management approaches at four USA university campuses; recognize such advanced solutions to control parking demand and supply by surveyed the results of parking management strategies in 300 universities; and suggest a agenda to examine the correlation between parking management and community aspects.

The Institute of Transportation Engineers (ITE) manual gathers data from different surveys carried out in North America. For the university or college areas, the ITE collected data from 11 university campuses in Canada and the United States. ITE parking generation manual suggested various characteristics and formulas for universities located in urban and suburban areas (ITE, 2010). A number of universities campuses parking studies in the literature compare their data with the results of ITE parking generation manual (Zein et al., 2008 and Sofia et al., 2012). Zein et al. (2008) used the ITE manual to study the characteristics of University of Victoria in Canada, to establish a parking supply and management strategy, and to minimize conflicts while supporting safe and well-organized movement within the campus for entirely campus users. In addition to that the study recommended the possible future parking locations based on existed parking supply and demand.

Parkers' questionnaire survey has been conducted by many researchers to investigate the parking users' behavior in universities campuses. Different suggestions and strategies were given by researchers regarding the universities campuses parking development on the basis of parking characteristics and environment (Aoun et al., 2013, Zein et al., 2008 and Sofia et al., 2012). Based on 200 participants for questionnaire survey, Boob et al. (2018) have also presented suggestions to find out solutions for the illegal parking and parking concerns that faced parkers in the gates of the MIT campus college -Pune, Maharashtra.

Also, to evaluate parking demand and future parking needs at Salem State University (SSU) in Massachusetts, USA, an online survey was conducted for two groups which were SSU community and SSU neighborhood area. Several recommendations were drawn from the survey which were related to permits and parking space 
distribution, new parking locations, pedestrian access improvements, exist and future demand management, and enforcement strategies (SSU, 2018).

For the purpose to regulate the necessary parking space for any system, the characteristics and specific requirements that have an important effect on planning for parking spaces necessity be studied. Also, appropriate parking policies should be identified to apply within the system. The quantity of parking locations and the practical method in which parking areas are occupied (Aswad, 2003).

The UoD main campus population increased intensely during the last five years by more than 3700 people (UoD registration, 2019). Subsequently, this advances a series problem that the uninterrupted growing of university population without appropriate strategy for traffic and parking policies for parkers when reach the university campus. Though numerous parking lots had been provided surround colleges in the campus, parkers at many times are quiet having parking problem and the campus suffer from many prohibited on-street parked cars. Furthermore, many people visit the university campus because of prevalent of some vital officers. These officers are conference hall, students' center, cultural center, Zanko bank, students' accommodation buildings, university common library, and campus registration directorate.

From the previous reasons, this study aims to evaluate the main parking characteristics and to assess the existing parking supply in UoD main campus. Furthermore, the study objectives are to detect the parking peak hour/s, to determine the maximum necessary parking spaces, to evaluate the parkers' behavior within the campus, to suggest appropriate parking situation/s in the campus, and to present recommendations and proposed solutions that can be taken into account for the afterward several years parking demand.

\section{STUDY METHODOLOGY}

Inclusive surveys were conducted in the university of Duhok main campus to recognize the existed parking problem, provide the necessary information associated to the campus parking lots distributions, and propose suitable solutions to solve the problem of parking within the university campus. In the period between October, 2019 and February, 2020, a general survey carried out to investigate the current campus land use and divided the campus area into zones. Then, four parking surveys were carried out to collect the necessary data. These surveys are: inventories for the illegal and legal parking situations in the campus, computing the area of the available lots, license plate survey and questionnaire survey for campus parking users'. Details of these surveys are elucidated in the subsequent units.

\subsection{Campus Zones}

UoD main campus has an approximate area of $\left(2.33 \mathrm{~km}^{2}\right)$ and located near to Zakho Street in a suburban area in the west part of Duhok city in Iraq. The university involves of 18 colleges; however, its main campus includes only 11 colleges with the Fine Arts institute building. Furthermost of these colleges have a number of departments, either in the same building or in separate buildings. Figure (1) shows the distribution of the colleges and institute over (9) zones in the main campus.

\subsection{Inventory of parking locations}

Using the master plan of the UoD main campus that offered by the university registration director (UoD registration, 2019), the inventory of parking locations that serving the university campus has been carried out. Information on this parking inventory is presented in below sections.

\subsubsection{Campus On-Street Parking}

The inventory of campus on-street parking was carried out and shown that the university traffic police were inhibited vehicles to park along all campus curbs. This is due to limited 
capacity of roads, required safety for vehicles and pedestrian, and provided a better flow of traffic inside the university campus. However, site observation showed that this is not certain of the situation and not controlled by traffic policemen because there are no strict instructions or fine applied. Besides, it is detected that signs placement are confusing in a number of locations and signs messaging are sometimes inconsistent. The most illegal on-street parking and traffic jam streets were found in zones 4,5 , and 6 due to many colleges departments in this area. These flexible parking allocations adversely affect the predictability and traffic flow in these zones.

\subsubsection{Campus Off-Street Parking}

The inventory of campus off-street parking locations was carried out and it was found that there were many parking lots used by campus parkers and their locations were not available in the campus master plan. This inventory included information on the parking location, type of pavement and its condition, type of parking users, fencing of lots and spaces marking. The results of this inventory indicated that there were 27 parking lots. These lots were mostly in good pavement condition and only four parking lots were unpaved. Most of the lots were accessible to be utilized by staff, all students and employers. All lots were fenced but mostly without space marks. Figure (1) demonstrates the locations of used parking lots in the campus.

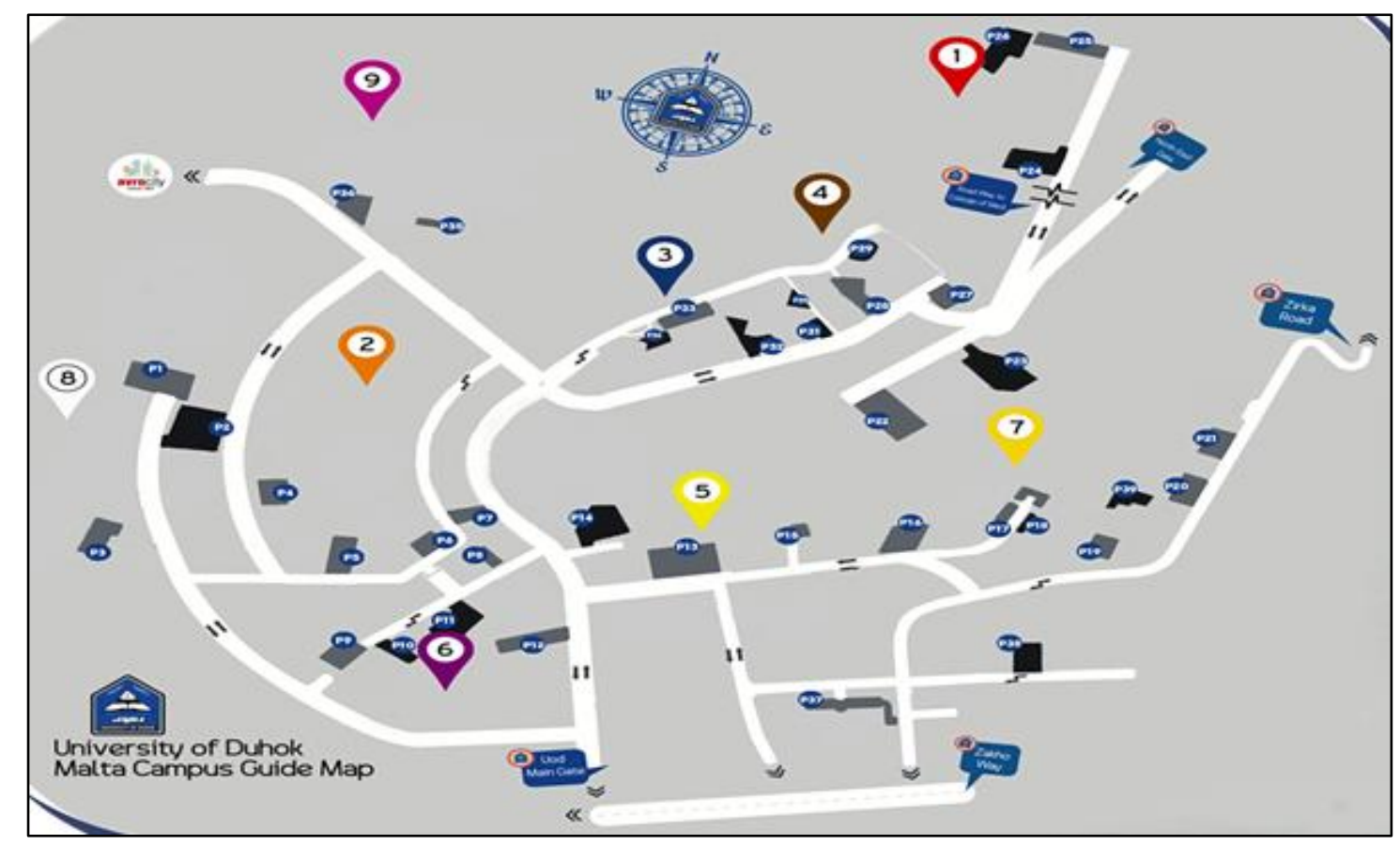

Fig. (1): Colleges and institute distribution over nine zones within UoD main campus (UoD registration, 2019)

\subsection{Computing the Area of the Available Lots}

Since furthermost of the available parking lots were with unmarked spaces, it was improbable to find out the accurate capacity of these lots. Thus, it was essential to find out the parking lot areas to conclude the actual available spaces in the campus. The parking areas found as follows:
1. Using the available master plan with AutoCAD Software to measure the parking lot areas for 15 locations in the campus.

2. Using Mobile Topographer Pro application to measure the parking lot areas for 12 locations in the campus which were unavailable in the master plan of the campus. The application has accuracy of (1.2 to 2.2) $\mathrm{m}$ with better accuracy than the 
global positioning system (GPS) (MTPA, 2019).

The total area reserved for parking for the campus colleges and institute with their calculated capacity in all nine zones are depicted in Table (1). The table realizes that the total area reserved for car parking lots was $\left(50956 \mathrm{~m}^{2}\right)$ which comprise of (27) locations. These locations consisted of around (2027) parking spaces based on $25 \mathrm{~m}^{2} /$ vehicle for each one parking space (Edward \& Whitlock, 1982). Moreover, the table shows that $25 \%$ of the parking lots areas are sited in zone 5 which utilized to serve parkers in Humanities colleges; however, the visual inspection found that zone 5 was the most crowded zone due to using illegal on-street parking.

Table (1): Measured parking areas and car parks capacities in the university campus

\begin{tabular}{|c|c|c|c|c|c|c|}
\hline Zones & Colleges and Institute & $\begin{array}{c}\text { Number } \\
\text { of } \\
\text { parking } \\
\text { lots }\end{array}$ & $\begin{array}{c}\text { Area } \\
\text { Reserved } \\
\text { for } \\
\text { Parking } \\
\left(\mathrm{m}^{2}\right)\end{array}$ & $\begin{array}{l}\text { Car parks } \\
\text { Capacities } \\
\text { (No. of Car } \\
\text { Spaces) }\end{array}$ & $\begin{array}{c}\text { Supply } \\
\text { Spaces } \\
(\%)\end{array}$ & $\begin{array}{c}\text { Population } \\
\text { in } \\
2018-2019\end{array}$ \\
\hline 1 & Medicine and Pharmacy Colleges & 3 & 5422 & 215 & 10 & 1191 \\
\hline 2 & Engineering College & 4 & 5362 & 213 & 11 & 1860 \\
\hline 3 & Science College & 3 & 5475 & 218 & 10 & 1922 \\
\hline 4 & Basic Teaching College & 2 & 2655 & 106 & 5 & 4429 \\
\hline 5 & Humanities College & 5 & 13017 & 518 & 25 & 3321 \\
\hline \multicolumn{7}{|c|}{ College } \\
\hline 7 & Law and Political Science College & 3 & 2954 & 117 & 7 & 444 \\
\hline 8 & Physical Education College & 3 & 9664 & 385 & 19 & 764 \\
\hline 9 & Fine Arts Institute & 2 & 2065 & 82 & 4 & 499 \\
\hline & Overall & 27 & 50956 & 2027 & 100 & 16865 \\
\hline
\end{tabular}

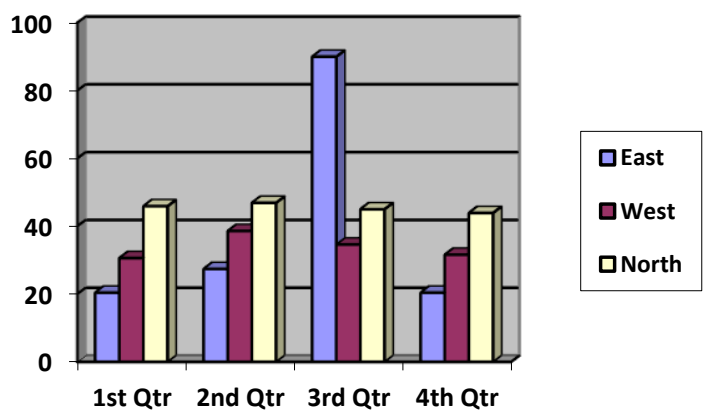

\subsection{License Plate Survey}

License plate survey was conducted to find out parking duration for each parked vehicle and to calculate the rate of utilization of offered spaces in the campus. Data on a typical weekday during nine hours (from 7:00 a.m. to 4:00 p.m) was abstracted from video records which were provided by the university police officer for the five gates of the main campus. These gates are: Malta main, North-East, Zirka roadway, Accommodation, and Avro City gates.

For all campus gates, all vehicles (arrived and departed) were observed and their license plate numbers were recorded. Two forms prepared for 
arriving and departing vehicles and then both forms matched to find parking duration of all parked vehicles in the university main campus or might be the vehicles where reached and departed the university without utilizing any parking space.

\subsection{Parking Users Questionnaire Survey}

Parking users' interview survey was conducted in the UoD main campus to assess the behavior of campus parkers. Along all campus colleges and institute departments, this questionnaire survey was conducted and motivated on parker who reached the campus by its own car. Sample size calculator software package was used to compute the descriptive sample size for interview survey and to reflect all campus parking users (SSC, 2019).

Because not all campus parkers have badges for entering vehicles, it was not possible to find out the actual parking users in the UoD main campus, and therefore, all campus population in (2018-2019) academic year were taken into account to find out the required sample size. 16863 individuals (15713 students, and 1150 staff and employees), and 5\% error margin with $95 \%$ level of confidence were considered to calculate a representative parking users sample size. It was found that 375 respondents were required. Though, a bigger sample was interviewed when total of (630) campus parking users were considered covering all college and institute departments.

The interviewers asked a series of questions, including: if they prefer on-street or off-street parking, parkers' origin, if they have parking problem or not, their parking duration, and if on-street parking is a reason of congestion in streets or not. The parking interview form is shown in Figure (2).

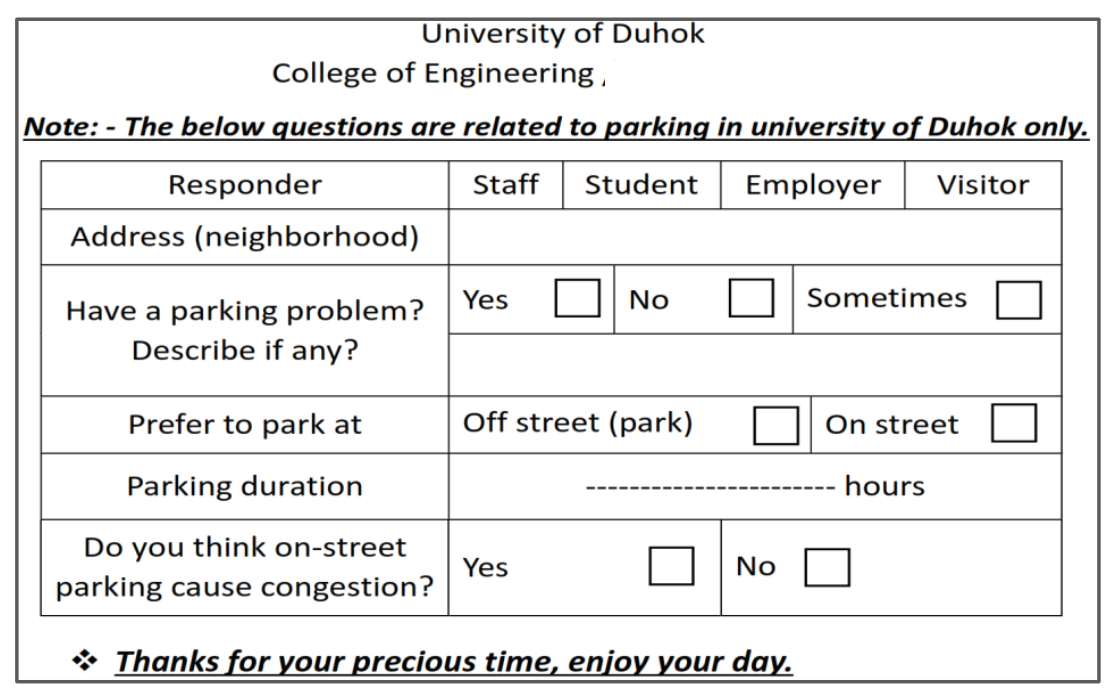

Fig. (2): Parking interview form

\section{UOD MAIN CAMPUS PARKING CHARACTERISTICS}

University campus parkers' characteristics and the characteristics of campus parking locations have a considerable effect on campus development. Information on these characteristics is needed for predicting the current and future parking demand, and recommended appropriate parking management practices and policies. The following sections provide the UoD main campus parking characteristics, and the recent and future parking needs.

\subsection{Existing Parking Supply}

The inventory of existing locations of car 
parks in UoD main campus indicated that parking vehicles along all the curbs of streets were illegal and constrained by campus police. Though, it was also shown that the university campus has a total of 27 lots which consist of 2027 parking spaces. This means that the existing proportion of accessible parking locations to the population of university main campus is about $12 \%$.

The results of parking lots inventories indicated that only $19 \%$ of these lots were marked, where unmarked lots lead to disorganized parked vehicles to occupy additional spaces. However, $89 \%$ of these lots were fenced which is referred to theses lots could be more safety and easier to calculate their area based on boundary limits. $85 \%$ were paved lots (rigid or flexible pavements) in which $89 \%$ were in good pavement condition. In addition, about $44 \%$ of available parking lots were available to be utilized by staff, students and employees and only $30 \%$ were reserved for staff only. Also, only $41 \%$ of colleges parking users were used legal parking spaces (i.e. parking lots) and the others were used on-street curb to park in addition to the available parking lots.

\subsection{Parking Accumulation and Current Demand}

Parking accumulation means the total number of cars parked in a given area at a particular interval of time. By using the data of arriving and departing vehicles to the university campus, parking accumulation counts were gained by assembling the variances between arriving and departing vehicles that serving the university campus in half an hour time interval. These accumulation data are shown in Table (2).

It can be seen that, from 7:00 to 7:30 a.m., only 144 vehicles were parked. Then the number of parkers gradually increased to reach the peak parking accumulation between 10:30 to 11:00 a.m. when a total of 1896 vehicles parked in the campus. After 11:00 a.m. the number of parked vehicles dropped gradually reaching the minimum at 4:00 p.m., which is the end of recording data collection, as shown in accumulation histogram in Figure (3). This indicates that the peak parking demand to current campus population is 0.11 which means $11 \%$ of parking space utilized during the peak time for each member of the university campus community.

Table (2) also shows the parking index for parking locations in the university campus, which is defined as the percent of the number of vehicles parked, divided by the total number of existing legal parking spaces (2027 spaces). In other words, it is parking demand and occupancy each 30 minutes for existing parking spaces. At 7:30 a.m., the utilization of the available parking spaces was only $7.1 \%$, and then the usage of spaces begins to increase continuously until reached the peak hour at 11:00 a.m. when the parking index $93.5 \%$. This indicates that the available spaces were not overloaded by the number of parkers that occupied these spaces at maximum parking accumulation. However, the visual inspection showed that a large numbers of illegal on-street parked vehicles at the peak hour. This could be due to unmarked parking lots where disorganized vehicles occupied extra spaces and others drivers search for facilitator option (i.e. on-street parking), where there are no strict parking policies.

Nevertheless, when parking occupancy is $85 \%$ to $90 \%$, parking supply operates at peak efficiency. Once the parking occupancy exceeds this limit, it is expected that there are interruptions and frustration in detecting an available space. In this case, the parking supply can be supposed as insufficient even still there are available spaces in the campus (Arbatskaya, 2007). Thus, there are inadequate parking supply spaces in UoD main campus because its parking occupancy is $93.5 \%$ during peak parking demand period (10:30 - 11:00) a.m.

In this case study, if $90 \%$ is considered as the efficiency factor with the understanding that the 
campus has a regular parkers and conversant with using available parking lots. Thus, parking demand calculated by dividing the observed demand (parking accumulation $=1896$ ) at peak period over the 0.9 of efficiency factor. The campus parking spaces deficiency or excess can calculate by the differences between expected demand and available supply. The parking demand generated by university campus population during peak time was about 2107 vehicles. The difference between the existing parking supply (2027) and peak demand (2107) specifies that there was a scarcity of 80 parking spaces where need to be providing to accommodate the current demand where it was accommodated by illegal on-street parking. However, if the efficiency factor assumed to be $85 \%$, there was a deficient of 204 parking spaces in the campus.

Parking load corresponds to the total area under the accumulation curve. Normally, trapezoidal rule at each half interval is used to measure the area under accumulation curve. It is expressed as vehicle-hour. As example for computing parking load for time between 10:3011:00 a.m., the area under the accumulation curve is $1884.5=[(1873+1896) / 2]$ and then this value is multiplied by half an hour period (1/2 hr). Thus, the parking load is (942.25) between 10:30-11:00 am. In this campus study, the total parking load for the period from 7:00 a.m. to 4:00 p.m. are (10511) vehicle-hour as illustrated in Table (2). This is indicated that if each parking space has been utilized efficiently, the average parking duration can be obtained by dividing the total parking load by the total number of vehicles that parked throughout the entire survey period.

Parking volume is defined as the overall number of vehicles that park in the campus over a given survey period time. From the license plate survey at all campus gates, data of all vehicles that arrived and departed were counted and matched to determine the total volume of parked vehicles in the campus and the number of vehicles that reached or left the university campus without parking during study period time, from 7:00 a.m. to 4:00 p.m. (9 hours). 
Journal of University of Duhok, Vol.23, No.2 (Pure and Eng. Sciences), Pp 584-600, 2020 (Special Issue) $3^{\text {rd }}$ international conference on recent innovations in engineering (ICRIE) Duhok, September 9-10-2020

Table (2): Parking accumulations and parking index in UoD main campus

\begin{tabular}{lccccc}
\hline \multicolumn{1}{c}{ Time } & Entering & Exiting & $\begin{array}{c}\text { Parking } \\
\text { Accumulation } \\
\text { (Parked } \\
\text { Vehicles) }\end{array}$ & $\begin{array}{c}\text { Parking } \\
\text { Index \% } \\
\text { (Utilization) }\end{array}$ & Parking load \\
\hline 7:00-7:30 a.m. & 156 & 12 & 144 & 7.1 & 36 \\
\hline 7:30-8:00 & 470 & 83 & 531 & 26.2 & 168.75 \\
\hline 8:00-8:30 & 1307 & 495 & 1343 & 66.3 & 468.5 \\
\hline 8:30-9:00 & 1248 & 899 & 1692 & 83.5 & 758.75 \\
\hline 9:00-9:30 & 531 & 503 & 1720 & 84.9 & 853 \\
\hline 9:30-10:00 & 314 & 230 & 1804 & 89.0 & 881 \\
\hline 10:00-10:30 & 343 & 274 & 1873 & 92.4 & 919.25 \\
\hline 10:30-11:00 & 299 & 276 & 1896 & 93.5 & 942.25 \\
\hline 11:00-11:30 & 283 & 314 & 1865 & 92.0 & 940.25 \\
\hline 11:30-12:00 & 325 & 347 & 1843 & 90.9 & 927 \\
\hline 12:00-12:30 p.m. & 320 & 419 & 1744 & 86.0 & 896.75 \\
\hline 12:30-1:00 & 390 & 573 & 1561 & 77.0 & 826.25 \\
\hline 1:00-1:30 & 467 & 664 & 1364 & 67.3 & 731.25 \\
\hline 1:30-2:00 & 546 & 921 & 989 & 48.8 & 588.25 \\
\hline 2:00-2:30 & 501 & 954 & 536 & 26.4 & 381.25 \\
\hline 2:30-3:00 & 285 & 99 & 4.9 & 158.75 \\
\hline 3:00-3:30 & 20 & 17 & 0.8 & 29 \\
\hline 3:30-4:00 & 392 & 0 & 0.0 & 4.25 \\
\hline & & & & \\
\hline
\end{tabular}

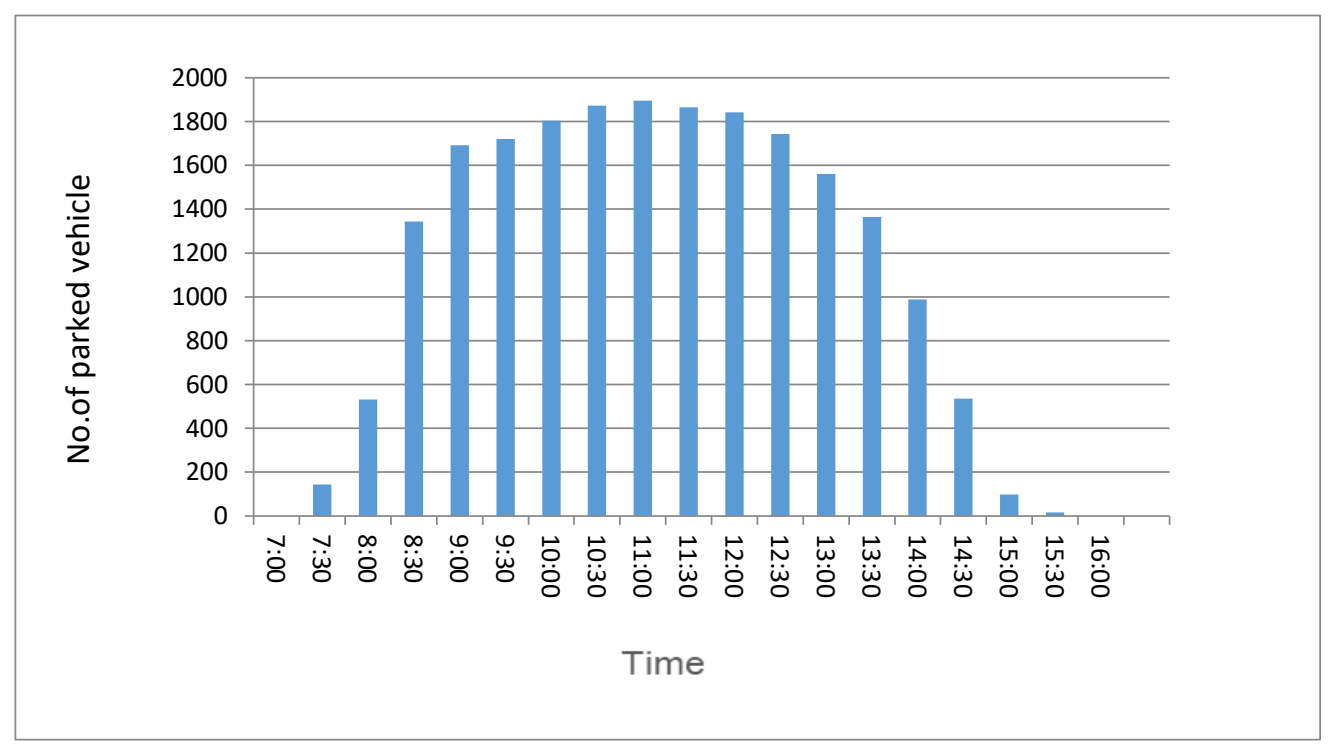

Fig. (3): Parking accumulations data of total parked vehicles in the university main campus 
It was observed that the number of recorded vehicles were 7805 , when their entering and exiting times were documented. However, these vehicles were not considered as all parked vehicles, because there were a number of recorded vehicles with only observing their arrival and departure times at all campus gates. The data from video records were not display the vehicles which were arrived before 7:00 a.m. and remained after 4:00 p.m.; this confirms that they have used the parking locations but their durations of parking were unidentified. Therefore, these vehicles were considered as parked vehicles and their average number were 388 vehicles. On average, there were 8,193 vehicles arriving and departing the $\mathrm{UoD}$ main campus every day.

Nevertheless, all vehicles need formal spaces and take period of time for searching and parking on the university campus, thus vehicles that have a short time duration stay on the campus should be ignored such as Taxies (Huayan et al., 2007). In this study, due to campus great area and the far distant between gates, the vehicles that had parking durations less that 30 minutes were neglected because entering from one gate and exiting from another gate could take about 30 minutes, and this indicated that they had not used parking spaces.

The numbers of those vehicles was 2636 and out of these $45 \%$ were Taxies, which means they did not park their cars and might be only picked up and dropped off in certain times. As a result, after ignoring the number of vehicles with short times of parking, the campus parking volume was 5557 vehicles.

\subsection{Parking Duration}

The average parking duration for vehicles parked in UoD main campus was measured from license plate survey data. This average duration was only equal to $01: 08 \mathrm{hr}: \min$ (1.13 hours) due to large number of parkers (2636 vehicles) with very short parking duration (i.e. less than half an hour), as shown in Figure (4). The figure shows that the majority of parkers were stayed for short parking duration (i.e. less than 2 hours), irrespective of these, the maximum numbers of parkers that have duration between 5 to 6 hours and then between 4 to 5 hours. Also, Figure (5) shows the cumulative frequency distribution of parking duration for an interval period of 1 hour. The $85 \%$ of campus parkers which stay less than duration stated is equivalent to $4: 30 \mathrm{hr}$ :min and the median (50th percentile) is less than 1 hour, while 15 th percentile is less than 30 minutes.

The average parking duration for each mode of travel was calculated. The highest average parking duration was 1.97 hours where utilized by private cars, coming next other types with 1.42 hours and then buses and taxis with $0.59 \mathrm{hrs}$ and $0.52 \mathrm{hrs}$, respectively. The largest percentage of parkers with short parking duration was about $81 \%$ of taxis (2240 vehicles) that stayed for less than one hour, while $45 \%, 78 \%$, and $52 \%$ of private cars, buses and other types. This indicates that the taxis with short parking duration are the most dominant mode of travel that causes on-street parking congestion in the university campus. Whereas, the longest parking duration (more than 2 hours), for private cars and buses that utilized the spaces have duration between 5 to 6 hours, for taxis have duration between 2 to 3 hours, and for other types of vehicles have duration between 4 to 5 hours. 


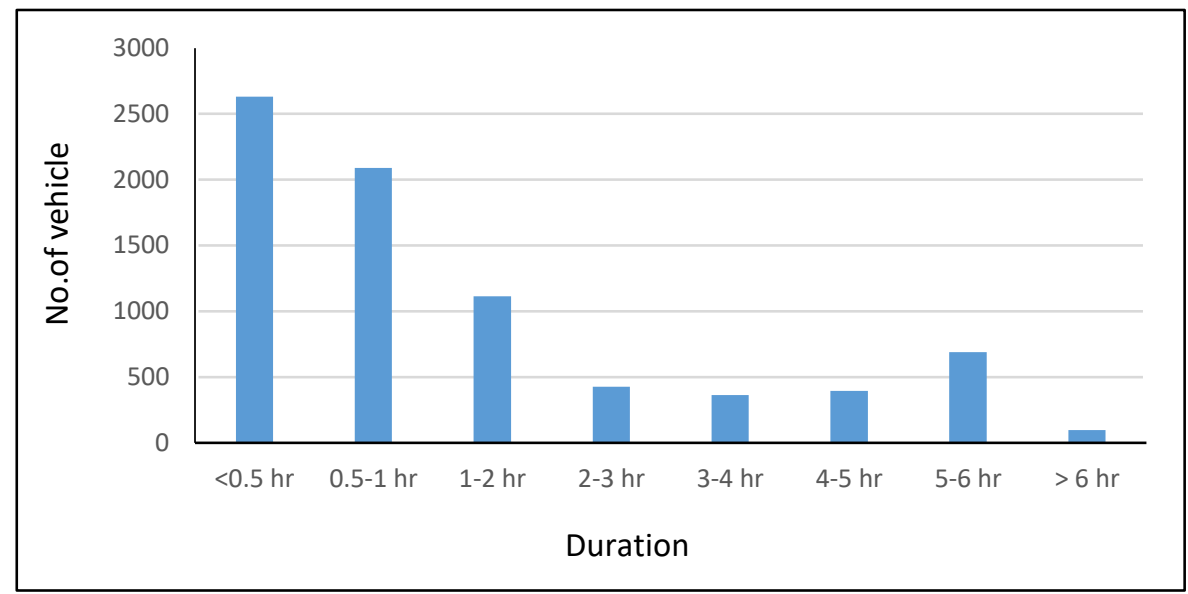

Fig. (4): Number of parkers with different parking duration in UoD main campus

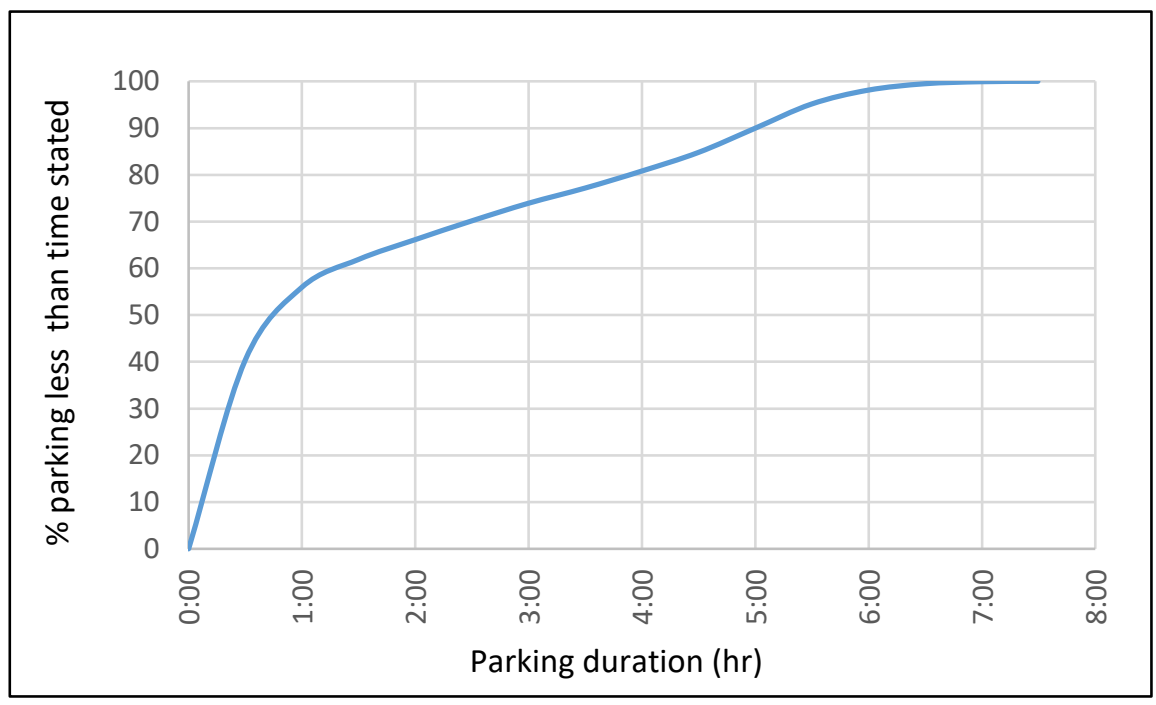

Fig. (5): Cumulative frequency distribution of parking durations

\subsection{Campus Parking Turnover}

Parking turnover defines as the rate of using parking spaces for a specific time period. It is considered by dividing the entire number of parked vehicles in the university campus (parking volume) into the total number of available parking spaces (Box and Oppenlaner, 1976). Hence, the average parking turnover for the campus was 2.74 vehicles per space, which is a fairly undersized term parking rate. This indicates that if only parking lot spaces utilize in the UoD main campus, each spaces might be utilized approximately three times during 9 hours, which is not a reasonable rate for campus parking. However, the circumstance that the campus parking demand is more than current supply requires more turnover value in utilizing the parking lots; but the improvement of turnovers is blocked by vehicles with long parking duration. This is a distinctive characteristic of university campus parking system, which differs from other communities systems.

\section{RESULTS OF PARKING USERS' INTERVIEW}

To assess the parking users' behavior in UoD main campus, 630 parking users' were responded from all colleges and institute within 
the main campus. Out of these respondents, $70 \%$ were students, $17 \%$ were staff, $9 \%$ were employers, and $4 \%$ were visitors.

The responses of parking users informed that the majority $(69 \%)$ of university parkers have a definitely or sometimes parking problem. Although, a number of colleges' parking lots were reserved only for staff and employees, still $50 \%$ of staff members and $45 \%$ of employees claimed that they have parking problem in the university campus. Also, $46 \%$ of students and most of visitors $(62 \%)$ have the problem of parking.

Though parking users prefer the shortest normal walking path, $70 \%$ of responders were preferred lots parking than on-street parking. This is because the on-street parking was illegal along all campus streets and staff, students and employers were aware of campus policies. However, visitor responders were preferred on-street parking. In addition, $77 \%$ of parking users' respondent that they acknowledged on-street parking causes congestion in the campus streets. This is because most of the responders believe that except the visitors. Also, the majority of staff and employer members have parking duration between 5 to 6 hours, whereas students have duration between 4 to 5 hours and $50 \%$ of visitors have duration between 2 to 3 hours. The maximum numbers of parkers were those that have parking duration between 4 to 5 hours for all colleges, except medicine collage, law and political sciences collage, and fine art institute have parking duration between 5 to 6 hours.

\section{OPTIMAL SITUATION FOR CAMPUS PARKING LOT}

The success of selecting the optimal off-street parking services depends largely on their locations relative to generators of parking demand (Hintersteiner, 1989). The optimal location for the required car park to fulfill the present and future demand was determined using the method of moments (Hobbs, 1979). As the campus study area divided into 9 zones, then a scaled AutoCAD master plan map of UoD campus was used to find the optimal parking location. Figure (6) shows this location for building parking lot between zones 3 and 5, which could serve parking problem and help to reduce on-street parking congestion. However, another suitable location, close enough to this optimal location, can be developed with a large area of one or two parking lots. Constructing additional parking lots with accordance of population of each collage at each campus zone could be more accommodating to solve parking problem. 


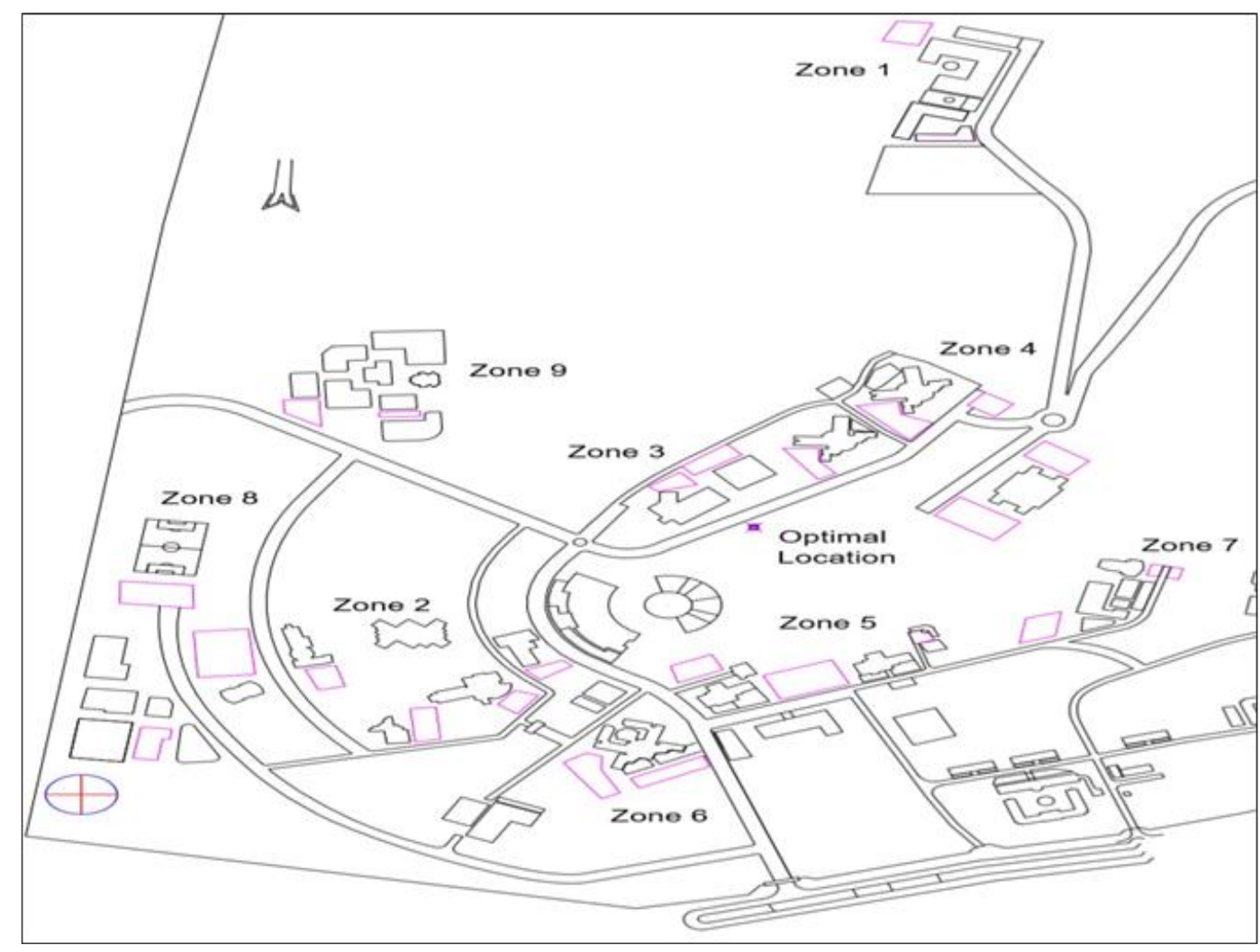

Fig. (6): Optimal situation of additional parking lot in the university main campus

\section{Future Campus Parking Demand}

UoD main campus faces the problem of an increasing the number of vehicles that park in the campus during the last five years due to continuous increase of campus population. Hence, because of the expected continuous progress of UoD campus population, further future parking demand will be generated. Also, other factors might provide more sustenance to increase this demand, such as using available campus land and increasing in number of private cars, if there are no suitable parking policies applied. Accordingly it is not conceivable to predict the campus population growth rate for any target year, and therefore, historic data of university population through the previous 5 years was utilized to calculate the percent of growth rate (Sofia et al., 2012). The university main campus population growth history (growth rate) is about $=6 \%$. Thus, Equation (1) was used to estimate future parking demand, as follows:

\section{Future parking demand $=$} Current peak parking demand $*(1+r)^{n}$ (1)

Where: $\mathrm{n}$ is the target years $=5$ years and current peak parking demand $=2107$

Future parking demand $=2107(1+0.06)^{5}$ $=2819$ parking spaces.

In other words, the future peak parking demand will be 2819 parking spaces which are estimated to reach to UoD main campus by the academic year (2023-2024).

Furthermore, the proportion for the current parking supply and peak period parking demand at the UoD main campus were compared to data supplied in the engineering standard reference 
manual which provided by the Institute of Transportation Engineers (ITE manual) (ITE, 2010). The manual provide information for both urban and suburban campuses, however, the UoD main campus may be categorized as a suburban university campus characteristics, because it is located in an area of comparatively moderate density development. Also, UoD main campus is physically accessible from the nearby communities and suburbs. The comparison results are presented in Table (3).

Table (3): Comparison between UoD parking measures proportion data and ITE manual data

\begin{tabular}{ccc}
\hline Parking Measure & \multicolumn{2}{c}{ Proportion } \\
\cline { 2 - 3 } & UoD & ITE \\
\hline Current parking supply / Campus population & 0.12 & 0.33 \\
(Supply proportion) & & \\
\hline $\begin{array}{c}\text { Peak parking demand / Campus population } \\
\text { (Demand proportion) }\end{array}$ & 0.11 & 0.30 \\
\hline $\begin{array}{c}\text { Optimal supply proportion } \\
\text { (1.15 of the Peak parking demand / Campus population } \\
\text { proportion) }\end{array}$ & 0.13 & - \\
\hline
\end{tabular}

By comparing UoD supply proportion (0.12) with ITE manual data (0.33), the UoD main campus has been providing 0.21 less parking spaces per person than the average parking supply rate that has been provided by ITE for suburban universities. This indicates that there is $64 \%$ deficiency in current parking supply in UoD main campus. Also, by comparing UoD main campus peak demand proportion (0.11) with ITE manual data (0.30), the UoD main campus has been providing 0.19 less parking spaces per person than the average peak parking demand rate that has been provided by ITE for suburban campus universities. This also refers to a $63 \%$ deficiency in peak parking demand in UoD main campus.

Table (3) also presents the optimal supply proportion of (0.13) spaces per campus population, which indicates a location where the parking supply would be $13 \%$ higher than the peak demand with $(0.11)$ spaces per current population. In other words, if the optimal supply of parking spaces is provided, the peak parking demand would be $87 \%$ of the supply all over the campus. This is could be a practical forecasting target to establish for major parking travelers in suburban campus.

These comparisons recommend that more aggressive and enhanced transportation demand management advantages beyond the current circumstances will probably be required, in order to avoid further shortages in the future demand for parking at the university campus.

\section{CONCLUSIONS}

From focusing the light upon the significant findings of this university campus parking study, the following conclusions have been drawn:

1. On-street parking vehicles along all the curbs of streets are illegal and constrained by campus traffic police department.

2. The UoD main campus has a total of 27 parking lots which consist of 2027 parking spaces. This means that the current proportion of existing parking supply to the university main campus population is about $12 \%$.

3. $19 \%$ of campus parking lots were marked, $89 \%$ of these lots were fenced, $85 \%$ were paved with either rigid or flexible pavements, $89 \%$ were in 
good pavement condition, and $44 \%$ were accessible to be used by all people. In addition, $41 \%$ of the collages parking users were utilized legal spaces and others were used on-street curb to park in addition to the available parking lots.

4. Peak parking accumulation in the university campus occurred between 10:30 to 11:00 a.m. when an overall of 1896 vehicles parked and the utilization of spaces reached the peak hour with parking index equal to $93.5 \%$.

5 . The parking demand generated by university campus population during peak time was about 2107 vehicles after considering the efficiency factor of $90 \%$. This indicates that the UoD main campus suffered from deficiency of almost 80 parking spaces where need to be provided to accommodate the current demand.

6. The campus total parking volume during 9 hours was 5557 vehicles. This was after taking into account to excluding 2636 vehicles that visit the campus for a identical short time period (less than 30 minutes). The campus total parking load for the period from 7:00 a.m. to 4:00 p.m. was 10510.5 vehicle - hour.

7. Average parking duration was only equal to 01:08 hr:min (1.13 hours) because of the majority of parkers were stayed for short parking duration (i.e. less than 2 hours), irrespective of these, the maximum numbers of parkers that have duration between 5 to 6 hours and then between 4 to 5 hours.

8. The highest average parking duration was 1.97 hours where utilized by private cars, coming next other types with 1.42 hours and then buses and taxis with $0.59 \mathrm{hrs}$ and $0.52 \mathrm{hrs}$, respectively.

9. Out of total short term parkers with parking duration less than 1 hour, about $81 \%$ were taxis, and $45 \%, 78 \%$, and $52 \%$ were private cars, buses and other types, respectively. This indicates that taxis with short parking duration are the most dominant mode of travel that causes on-street parking congestion in the campus.

10. The average parking turnover in the university campus per 9 hours was found to be 2.74 vehicles /space, which is a fairly undersized term for parking rate.

$11.69 \%$ of university parkers have mostly or sometimes a parking problem. Whereas $50 \%$ of staff members and $45 \%$ of employers claimed that they have parking problem in the university campus. Also, $46 \%$ of students and most of visitors $(62 \%)$ have the problem of parking. $70 \%$ of parkers were preferred off-street parking than on-street parking. However, visitor parkers were preferred on-street parking than off-street parking.

12. Proposed ideal location for required car park to be constructing in the university main campus was located between zones 3 and 5 .

13. The future peak parking demand is estimated to be 2819 parking spaces that ought to provide demand accommodations that produced by growing campus population, which are anticipated to attain to campus by the academic year (2023-2024).

14. Comparison between UoD main campus parking measures with ITE manual data, indicates that there is $64 \%$ deficiency in current parking supply and $63 \%$ deficiency in peak parking demand in UoD main campus.

\section{RECOMMENDATIONS AND PROPOSED SOLUTIONS}

As the study analysis points toward that the UoD main campus future parking demand is anticipated to surpass the existing parking supply. Taking into account all of the information as concluded above, the university have a duty to 
consider the following recommendations and proposed solutions:

1. Establishing clear parking policy and firmly applied concerning parking license badges (stickers) in agreement with the existing spaces in each collage. This means that all students, employees, and staff must have permit label to park on university campus.

2. Improving the current parking lots by paving the unpaved parking lots and space marking.

3. Increasing the campus parking supply by constructing additional parking lots with accordance of population of each collage at each campus zone. Also, providing suitable and appropriately located one or more parking capacity for the university community.

4. Appling a strict policy for taxis that entering and exiting multiple times and allocate specific parking locations for these taxis with limiting their numbers, despite the fact that encouraging and facilitating alternative modes of travel to be used.

5. Improving transportation system within the university campus by providing public transport mode of travel for transporting and circulating students among campus buildings and gates.

6. Installing of guide signs for prohibited parking curbs along on-street and specifically near to collages entries because the on-street parking has produced a series of campus problems, comprising traffic congestion, and consequently is unsafe for pedestrians crossing.

7. Managing the transportation demand with an assignment and setting a price for all parking areas to control the uses of private cars and shift people to use public transport.

It is anticipated that the methodology used in this campus parking study can be used for solving of comparable problems prevailing in other universities campuses, particularly in campuses with a large areas and multiple accessible gates.

\section{REFERENCES}

Aoun, A., Abou-Zeid, M., Kaysi, I., Myntti, C. (2013). Reducing parking demand and traffic congestion at the American University of Beirut. Transport Policy Journal, 52-60.

Arbatskaya, M., Mukhopadhaya, K., \& Rasmusen, E. (2007). The Parking Lot Problem. Indiana University, Kelley School of Business, Department of Business Economics and Public Policy,

Aswad, N. H. (2003). Parking Characteristics Study and their Effect in Dohuk City Center. M.Sc. Thesis, University of Salahaddin, Erbil, Kurdistan region, Iraq.

Boob, R., Biswas, A. P. (2018). Analysis for the Need of Parking Management System in Campus of MIT College. International Research Journal of Engineering and Technology (IRJET), Volume: 05, Issue: 05 .

Box, P. C. \& Oppenlaner, J. C. (1976). Manual of Traffic Engineering Studies. (4 ${ }^{\text {th }}$ ed.), Institute of Transportation Engineers, Washingotn.

Coulson, J., Roberts, P., \& Taylor, I. (2011). University Planning and Architecture: The Search for perfection. 263 pp. ISBN: 978-0415-57110-4 Routledge: New York. 14.

Edward, M. \& Whitlock, P.E. (1982). Parking for institutions and special events. ENO Foundation for Transportation, Inc., Westport, Connecticut.

Hamo, D. S., Malaika M., \& Namo, Q. (2018). Planning to Control Traffic Congestion in Duhok University Campus. Journal of University of Duhok., Vol. 21, No.1 (Pure \& Eng. Sciences), 97-110.

Hintersteiner, R. T. (1989). Parking Control Guidelines for the Design of Parking Facility Portals. Institute of Transportation Engineers, Vol. 59, No. 1, pp. 28-31.

Hobbs, F.D. (1979). Traffic Planning and Engineering. Pergamum International Library of Science, (2nd ed.), 173-208. 
Huayan, Sh., Wenji, L., \& Haijun, H. (2007). Empirical Study of Parking Problem on University Campus, Journal of Transportation Systems Engineering and Information Technology, Volume 7, Issue 2.

ITE, Institute of Transportation Engineers (2010). Parking Generation. (4th ed.), an ITE Informational Report, Institute of Transportation Engineers, Washington, D.C.

Janak P., Pritikana D., Sanjaykumar M. D. (2020). Study on demand and characteristics of parking system in urban areas: A review. Journal of Traffic and Transportation Engineering ,Vol. 7, No. 1, February 2020, Pages 111-124.

MTPA (2019). Mobile Topographer Pro Application, http://applicality.com/projects/mobile-topogra pher-pro/, accessed on October, 2019.

Sofia, G. G., Jabbar A., \& Kraidi, R. A.B. (2012). Parking Study in Al- Mustansiriya University
Main Campus. Journal of Engineering and Development, Vol. 16, No.2, ISSN 18137822.

SSC (2019). Sample Size Calculator, https://www.surveysystem.com/sscalc.htm, accessed on October, 2019.

SSU (2018). Campus Parking Study, Salem State University. Massachusetts, USA, Final Report, April, 2018.

UoD registration (2019. University of Duhok, Main Campus registration office, November, 2019.

Zein, S., Bathurst, Ch., \& Chow, K. (2008). Traffic and Parking Management Study, University of Victoria Report, 2008.

Cheu, R. L., Gurbuz, O., Balal, E. H., Zhang, M. H., Gao, O., Zhang, Y. (2018). Characterization of University Parking System. Final Report, Center for Transportation, Environment, and Community Health, U.S. Department of Transportation. 